References

1 Smith R. "We get on each other's nerves:" unemployment and the family. Br Med $\mathrm{J}$ 1985;291:1707-10.

2 National Society for the Prevention of Cruelty to Children. Information briefing: an overview of the research on the effects of unemployment on the family with particular reference to child abuse. London: National Society for the Prevention of Cruelty to Children, 1985.

3 Cater JI, Easton PM. Separation and other stress in child abuse. Lancet 1980;i:972-4.

4 Madge N. Unemployment and its effect on children. Joumal of Child Psychology and Psychiaty 1983;24:311-9.

5 Young L. Wednesday's children: a study of child neglect and abuse. New York: McGraw-Hill, 1964. 6 Galdston R. Observations on children who have been physically abused and their parents. Am J Psychiatry 1965;122:440-3.
7 Gil DG. Physical abuse of children: findings and implications of a nationwide study. Pediatrics 1969;44:857-64.

8 Creighton SJ. Child victims of physical abuse 1976: third report on the findings of NSPCC special units registers. London: National Society for the Prevention of Cruelty to Children, 1980.

9 O'Brien TE. Violence in divorce prone families. Jourmal of Marriage and the Family 1971;33. 292-8.

10 Steinmetz SK, Straus MA. Violence in the family. New York: Dodd and Mead, 1974.

11 Lynch MA, Roberts J. Consequences of child abuse. London: Academic Press, 1982.

12 Oliver JE. The epidemiology of child abuse. In: Smith SM, ed. The maltreatment of children. Lancaster: MTP Press, 1978.

(Accepted 27 February 1987)

\title{
What are health authorities doing about the health problems caused by unemployment?
}

\author{
CHRISTIANE HARRIS, RICHARD SMITH
}

\begin{abstract}
Unemployment is over three million in Britain, and unemployment is known to be associated with poor health. It has been suggested that health authorities should produce a comprehensive response to the health problems caused by unemployment, and a survey was undertaken to find how many had done so. All the regional and district health authorities in England, the health boards of Wales, Scotland, and Northern Ireland, and the family practitioner committees of England and Wales were asked by letter what they were doing to respond to the health problems of unemployment. A list of suggestions of what they might be doing was enclosed. The overall response rate was $77 \%(255 / 331)$, and $50 \%(127 / 255)$ of the respondents were doing something - $33.3 \%$ (3/9) of the regional health authorities, $64 \%(101 / 158)$ of the district health authorities and health boards, and $26 \%(23 / 88)$ of the family practitioner committees. The paper describes what they were doing. A relation was sought between the level of unemployment in an area and the extent of the response, and a significant association was found.
\end{abstract}

Half of Britain's health authorities are now responding in some way to the health problems associated with unemployment.

\section{Introduction}

More than three million people are unemployed in Britain, and unemployment is strongly associated with poor health. ${ }^{1.5}$ Unemployed middle aged men have a death rate twice that of comparable men in employment. ${ }^{6}{ }^{7}$ Unemployment itself, rather than its common companions such as poverty and poor housing, causes a deterioration in mental health ${ }^{18}$ and is strongly associated with suicide and parasuicide. ${ }^{9}$ Those who are threatened with losing their jobs consult their general practitioners $60 \%$ more often than controls who are in work and are referred $20 \%$ more often for hospital outpatient appointments. ${ }^{10}$

Some have thus argued that health authorities should develop

University College London, London WC1E 6BT

CHRISTIANE HARRIS, BSC, medical student

British Medical Journal, BMA House, London WC1H 9JR

RICHARD SMITH, BSC, MB, assistant editor

Correspondence to: Dr Smith. plans for responding to the health problems of the unemployed, ${ }^{3} 11$ but there is little or no published evidence that any have done so. We have attempted to find out how many health authorities are responding to the health problems of the unemployed and what they are doing. We have also tested the hypothesis that authorities in areas of high unemployment may have done more than those in areas of low unemployment.

\section{Methods and results}

In October 1986 we contacted by letter the regional and district health authorities in England, the health boards of Wales, Scotland, and Northern Ireland, and the family practitioner committees of England and Wales. (Family practitioner committees in the rest of the United Kingdom were not contacted simply because we did not have time.) We asked the authorities to tell us what they were doing about the health problems caused by unemployment and as a prompt enclosed a list of eight measures that migh be taken (table I). If the authorities were doing nothing then we asked them

TABLE I-Steps that might be taken to respond to the health problems of unemployment

(1) Monitoring unemployment and its effects on health in your area

(2) Relaying this information to staff

(3) Taking unemployment into account when allocating resources

(3) Taking unemployment into account when allocating resources
(4) Creating jobs and work-either on your own initiative or together with the Manpower

(4) Encouraging and training staff to familiarise themselves with facilities and benefits for the unemployed, and perhaps seconding some to local community initiatives

(5) Making information about facilities and benefits for the unemployed available to staff. Such facilities include:

advisory bodies

counselling/psychological help

job creation schemes

leisure/recreation schemes

retraining/education

practical skills (such as furniture repair and preparation of cheap but nutritious meals)

women's groups

youth groups

(6) Liaising with local authorities and other health authorities to ensure that efforts are not being duplicated and to assess whether you could do anything to further their efforts (7) Targeting your responses at those most at need

to write "none" on our letter, stamp it with the authority's stamp, and return it in the enclosed stamped addressed envelope. A reminder was sent to all non-respondents after one month.

More than three quarters $(77 \%, 255 / 331)$ of the authorities responded: $64 \cdot 3 \%(9 / 14)$ of the regional health authorities, $72 \cdot 1 \%(158 / 219)$ of the district health authorities and health boards, and $85 \%(83 / 98)$ of the family practitioner committees. Respondents were compared with non-respondents by looking at the proportions with unemployment rates that were high $(15 \%$ 
or greater), medium (10.1-14.9\%), and low ( $10 \%$ or less), and no significant difference emerged (table II).

Overall, $50 \%(127 / 255)$ of the respondents were doing something to help the health problems of the unemployed: $33 \cdot 3 \%(3 / 9)$ of the regional health authorities, $64 \%(101 / 158)$ of the district health authorities and health boards, and $28 \%(23 / 83)$ of the family practitioner committees. Table III shows what they were doing.

TABLE II-A comparison of those who did and did not respond to a request for information on steps taken to respond to the health problems of the unemployed

\begin{tabular}{|c|c|c|c|}
\hline Unemployment rate & No of respondents & No of non-respondents & Total \\
\hline \multicolumn{4}{|c|}{ District health authorities } \\
\hline $\begin{array}{l}\text { Low } \\
\text { Medium } \\
\text { High }\end{array}$ & $\begin{array}{l}33 \\
73 \\
52\end{array}$ & $\begin{array}{r}8 \\
33 \\
20\end{array}$ & $\begin{array}{r}41 \\
106 \\
72\end{array}$ \\
\hline Total & $\begin{array}{l}158 \\
\chi^{2}=1.96, d\end{array}$ & $2, p>0 \cdot 1$ & 219 \\
\hline \multicolumn{4}{|c|}{ Family practitioner committees } \\
\hline $\begin{array}{l}\text { Low } \\
\text { Medium } \\
\text { High }\end{array}$ & $\begin{array}{l}10 \\
43 \\
30\end{array}$ & $\begin{array}{r}2 \\
3 \\
10\end{array}$ & $\begin{array}{l}12 \\
46 \\
40\end{array}$ \\
\hline Total & $\begin{array}{l}83 \\
\chi^{2}=5 \cdot 52, d\end{array}$ & $p>0.05^{15}$ & 98 \\
\hline
\end{tabular}

*Calculated from figures at 14 August 1986 . High $=15 \%$, medium $=10 \cdot 1-14 \cdot 9 \%$, low $=10 \%$. Although unsatisfactory, figures for London have had to be assessed according to the value given for Greater London (10.7\%) except where this was clearly too high-East Surrey, Merton and Sutton, Mid-Downs, North West Surrey, Richmond/Twickenham/Roehampton, and South West Surrey have all been counted as "low."

The figure shows which district health authorities and health boards were doing something and how much they were doing. Table IV shows how much district health authorities and health boards were doing in relation to the unemployment rate in their districts. There was a significant association: those in areas of high unemployment were significantly more likely to be doing more than those in areas of lower unemployment.

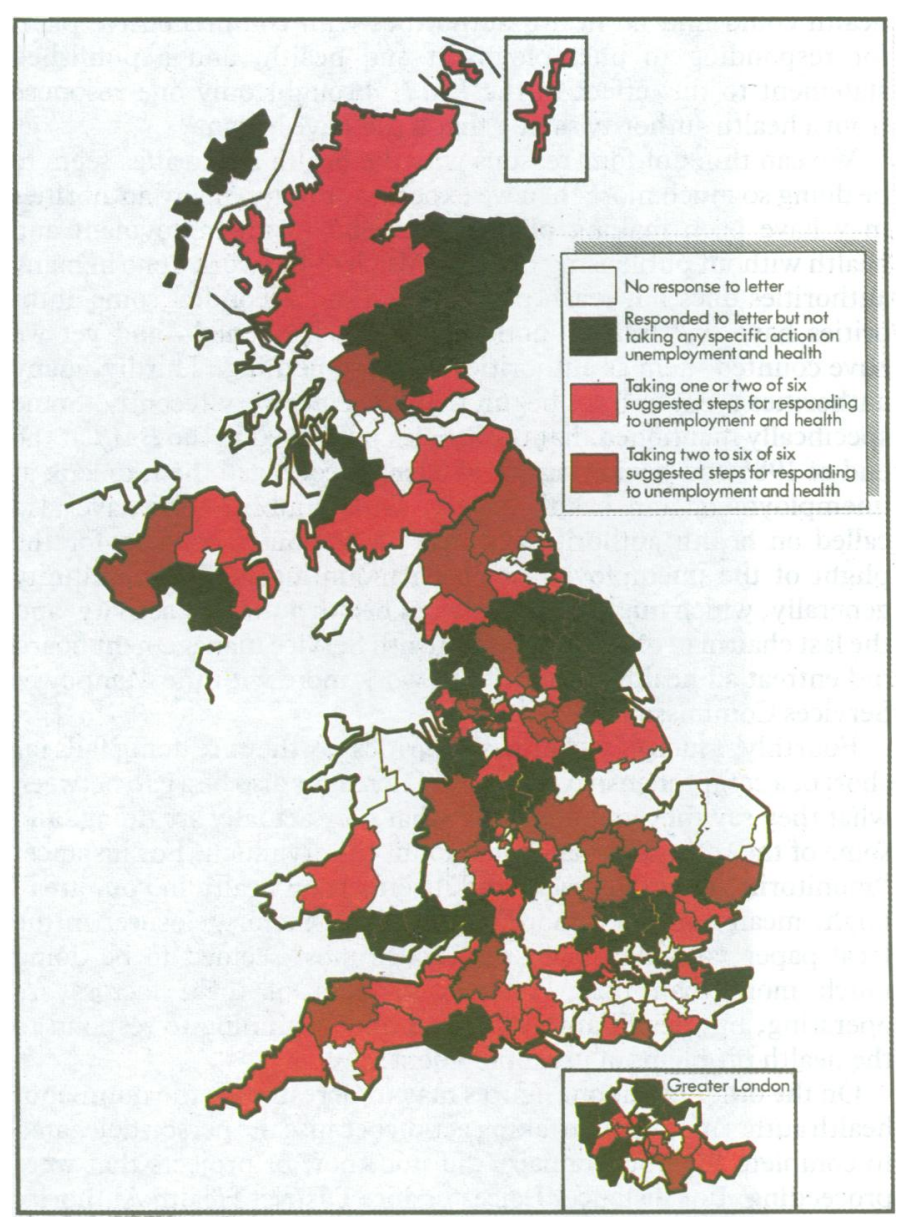

Response of district health authorities and health boards to the health problems of unemployment.

TABLE III-Response of health authorities, health boards, and family practitioner committees to the health problems of unemployment

\begin{tabular}{|c|c|c|c|c|c|c|c|c|}
\hline & \multirow[b]{2}{*}{ No } & \multicolumn{6}{|c|}{ Response $^{\star}$} & \multirow{2}{*}{$\frac{7}{7}$} \\
\hline & & 1 & 2 & 3 & $4 a$ & $4 b / 5$ & 6 & \\
\hline $\begin{array}{l}\text { Regional health authorities } \\
\text { District health authorities and health boards } \\
\text { Family practitioner committees }\end{array}$ & $\begin{array}{r}9 \\
158 \\
83\end{array}$ & $\begin{array}{r}0 \\
33 \\
4\end{array}$ & $\begin{array}{r}0 \\
15 \\
1\end{array}$ & $\begin{array}{r}0 \\
20 \\
4\end{array}$ & $\begin{array}{r}2 \\
65 \\
11\end{array}$ & $\begin{array}{r}0 \\
55 \\
7\end{array}$ & $\begin{array}{r}0 \\
13 \\
5\end{array}$ & $\begin{array}{r}1 \\
23 \\
7\end{array}$ \\
\hline $\begin{array}{l}\text { *1 Monitoring unemployment and its effects } \\
2 \text { Relaying this information to staff. } \\
3 \text { Taking unemployment into account when } \\
\text { 4a Creating jobs and work. } \\
\text { 4b/5 Training staff on facilities for the unem } \\
6 \text { Liaising with local authorities. } \\
7 \text { Targeting responses at those most in need. } \\
\text { Note: The questionnaire by mistake had two n } \\
\text { in our analysis. }\end{array}$ & $\begin{array}{l}\text { cally. } \\
\text { locatir } \\
\text { oyed. } \\
\text { nber } 4\end{array}$ & & & & & the & & ther \\
\hline
\end{tabular}

TABLE IV-The number of steps taken by district health authorities, grouped according to their unemployment rates

\begin{tabular}{lllll}
\hline & \multicolumn{2}{c}{ No of steps taken by respondents } & \\
\cline { 2 - 3 } & None & $1-2$ & $3+$ & Total \\
\hline Unemployment rate & & & & \\
Low & 17 & 12 & 4 & 33 \\
Medium & 23 & 35 & 15 & 73 \\
High & 17 & 17 & 18 & 52 \\
\hline Total & 57 & 64 & 37 & 158 \\
\hline
\end{tabular}

^Divisions as in table II.

$\chi^{2}=9 \cdot 53, \mathrm{df}=4, p=0 \cdot 05$

\section{Discussion}

We were surprised both by the high response rate and by the many authorities that said that they were doing something to respond to the health problems associated with unemployment. The small amount of work done previously on this topic suggested both that we would get a low response rate and that health authorities were not doing much. The only slightly similar previous survey-to see how many authorities were working with the Manpower Services Commission-had a very low response rate (G Forsyth, personal communication), and compared with local authorities only a small fraction of health authorities were reported in late 1985 to have taken on people through the Manpower Services Commission. One of us (RS) when researching a series on unemployment and 
health could find no health authorities with comprehensive plans for responding to unemployment and health, and a published statement to this effect in the $B M \mathcal{F}^{12}$ brought only one response from a health authority saying that it did have a plan. ${ }^{13}$

We can think of four reasons why the health authorities seem to be doing so much more than we expected. Firstly, many authorities may have been making plans to respond to unemployment and health without publicising the fact. Much of the work done in many authorities does not reach public attention. Secondly, some authorities have only plans-nothing has yet happened-and yet we have counted them as authorities doing something. Thirdly, many authorities seem to have begun their schemes very recently. Some specifically mentioned that the articles published in the $B M \mathcal{F}$ at the end of 1985 and beginning of 1986 had encouraged them to look at unemployment and health locally. Other publications have also called on health authorities to make a response; concern for the plight of the unemployed has been mounting in the community generally, which might be reflected in health authority activity; and the last chairman of the National Health Service management board did entreat all health authorities to work more with the Manpower Services Commission.

Fourthly, much of what the authorities say they are doing falls far short of a comprehensive response. There may also be a gap between what they say they are doing and what they actually are doing, and some of the responses may not amount to very much. For instance, "monitoring unemployment and its effects on health in your area" might mean not much more than noticing factory closures in the local paper, although from the replies most seemed to be doing much more than this. Probably all four of these factors are operating, but health authorities are now beginning to respond to the health problems of unemployment.

On the other hand, our figures may underestimate the number of health authorities that are taking action because the person delegated to complete the questionnaire did not know of projects that were proceeding. For instance, Leicestershire District Health Authority said that it was not doing anything, and yet it was the one authority that responded to the BMF's challenge that no health authority had a comprehensive plan. ${ }^{13}$

\section{RESPONSE OF FAMILY PRACTITIONER COMMITTEES}

Family practitioner committees are doing much less than district health authorities, but it is only because of recent changes in their intended functions that they are doing anything at all. They used to be almost entirely reactive bodies; now they may plan and manage but have few resources to do so. The respondent from Leeds Family Practitioner Committee observed: "Most family practitioner committees two years ago would have felt no obligation to reply nor would have seen any connection with family practitioner responsibilities. Today the situation has changed, but not all will respond." He continued: "We have only just learned to walk and as yet have no shoes."

Nevertheless, some family practitioner committees are taking some interesting initiatives. Leeds and Kent Family Practitioner Committees gave the most positive responses. Leeds hopes by 1987 to be able to produce a practice profile of unemployment, and Kent is hoping to correlate results of the first national workload study from general practice with local socioeconomic analyses. Kensington and Chelsea Family Practitioner Committee is starting a two year youth training scheme to teach the skills of medical and dental receptionists, and Cheshire Family Practitioner Committee is encouraging local doctors to employ counsellors under the terms of the ancillary staff scheme.

We hope that most family practitioner committees will begin to walk in their new shoes and develop strategies for responding to the health problems of the unemployed because it is at this grassroots level that most of the problems will be encountered and possibly prevented. Hospital services swallow up most of the money of district health authorities, and yet hospitals can do little more than patch up the damage caused by unemployment.
RESPONSE OF REGIONAL AND DISTRICT HEALTH AUTHORITIES AND HEALTH BOARDS

Regional health authorities are generally doing little, and clearly do not see responding to unemployment and health as their responsibility. It is, in their thinking, a job for the districts, and the district health authorities and health boards are at the moment doing the most. Many have produced "health profiles" of their districts that have included data on unemployment, and some have undertaken specific studies of the impact of unemployment on the work of particular hospitals or departments. Fewer authorities are relaying information on unemployment and health to their staff, but Milton Keynes District Health Authority has held seminars specifically to do so, and North Warwickshire District Health Authority is doing so in a quarterly booklet for staff.

A few districts take unemployment rates into account when allocating resources, but they have limited scope for doing this as most of their expenditure is on hospitals. Sunderland District Health Authority has developed community health projects specifically for areas of deprivation and high unemployment.

Some district health authorities are the largest employers in the United Kingdom and so have much more scope than family practitioner committees for taking on unemployed people through the many schemes run by the Manpower Services Commission. They have been criticised for being slow to do so, but our survey shows that $41 \%(65 / 158)$ of responding health authorities are now participating in such schemes. South Sefton Health Authority has led the way with working with the Manpower Services Commission and now uses more than 250 unemployed people on a wide variety of projects that include health promotion. ${ }^{14}$ is When conducted well these projects can benefit both the patients of the health authority and the unemployed, and Dr Hilary Hodge and others from South Sefton have produced a guide on how to make the projects work well. ${ }^{14}$ Halton District Health Authority has also used people on the community programme for health promotion, while East Cumbria District Health Authority has unemployed people acting as facilitators who work with health visitors and encourage groups such as mother and toddler groups. Unemployed people work as carers in some districts-for instance, Darlington District Health Authority has 110 long term unemployed people working on a variety of projects that include caring for the elderly in the community. Sometimes the unemployed are doing physical work-for instance, in the Highland Health Board, where they are building a wheelchair walkway at Craig Phadrig Hospital and a market garden at Craig Dunain Hospital.

Understandably there is suspicion about these schemes, particularly from trade unionists. They are worried both that "proper jobs" are being replaced and that unemployed people are being exploited by receiving low pay for doing sometimes unpleasant jobs that offer little training and little help for finding a proper job. Some districts said that trade union pressure had stopped them creating schemes and had even forced them to abandon schemes that had been started. These may of course be excuses for inaction.

Another problem with the programmes is that they can create extra costs for authorities that are already hard pressed. The unit general manager of the south east unit of Northumberland District Health Authority explained this difficulty clearly:

"The main problems are that we have to pay the going rate for the job and the Manpower Services Commission will only reimburse to approximately $£ 67$ a week and the work undertaken must not be that which would normally be done by employees of the organisation. This in particular is very difficult to match because we therefore have to look for special projects. The old work experience schemes used to allow us to employ individuals to actually learn skills such as gardening or clerical or typing work."

After working with the Manpower Services Commission the next most common activity that district health authorities are undertaking is to train their staff on the problems of unemployment and how to respond. And one of the main responses is to put the unemployed in touch with the many helpful schemes that are operating in the area. Some authorities have reportedly discouraged their employees from working in any coordinated way with 
unemployed people, but we have encountered many examples of the opposite. Sandwell District Health Authority, for instance, is hoping to appoint a team of a community psychiatric nurse, a health visitor, a health education officer, and a community health worker to work in areas of high unemployment. Somerset District Health Authority has taught some of its staff about benefits available to the unemployed, while West Lambeth District Health Authority has a health education department in Brixton that runs a 10 week course aimed at the unemployed among others. North Birmingham District Health Authority has produced a leaflet, "How does having time on your hands affect your health?" which details benefits for the unemployed and discusses the health and social problems that they might encounter.

Only a minority of district health authorities are working with local authorities, and it is usually a very informal link. Several authorities are trying to target resources to those most in need, but the respondent from Newcastle District Health Authority summed up the difficulties: local policy "includes positive discrimination in favour of inner city areas where unemployment is highest, but we are always conscious of the need to maintain a certain common standard of services across the district."

\section{RELATION BETWEEN UNEMPLOYMENT RATE AND RESPONSE OF HEALTH} AUTHORITY

We found a statistically significant association between local unemployment rates and how much district health authorities were doing to respond to the health problems associated with unemployment. Several respondents said that they had produced no specific plans because local unemployment was "low." This seems complacent when only three areas in Britain have unemployment rates of under $6 \%$.

Some respondents—but only a handful—were hostile to the idea that health authorities had any special responsibility to respond to the health problems associated with unemployment. The chairman of South Glamorgan Family Practitioner Committee replied: "I am not convinced that family practitioner committees, or for that matter general practitioners, have a prime responsibility in this area. I am cognisant that unemployment produces unhappiness and may precipitate depressive illness. I believe that medical practitioners and family practitioner committees should put the research to other, more appropriate areas."

\section{Conclusions}

Such chilly responses were very much the exception. We were both surprised and impressed by how much health authorities were doing. Whether they are responding in the best way is not known, and most are learning as they go along. We hope that health authorities will evaluate their programmes and share their experiences. Perhaps a conference might be called and a guide to successful projects produced.

We thank Julie Morris for statistical help.

\section{References}

1 Warr P. Twelve questions about unemployment and health. In: Roberts R, Finnegan R, Gallie D, eds. New approaches to economic life. Manchester: Manchester University Press, 1985. eds. New approaches to economic life. Manchester: Manchester
Anonymous. Unemployment and health. Lancet 1984;ii:1018-9.

2 Anonym Neus. Unemployinent and health. Lance 1984;i:1018-9. Centre for Professional Development. Unemployment: a challenge to public health. Manchester:
Department of Community Medicine, 1986.

4 Smith R. "Bitterness, shame, emptiness, waste": an introduction to unemployment and health BrMed f 1985;291:1024-7.

5 Smith R. Unemployment and health. Oxford: Oxford University Press (in press).

6 Moser KA, Fox AJ, Jones DR. Unemployment and mortality in the OPCS longitudinal study. Lancet 1984;ii:1324-9.

7 Moser KA, Goldblatt PO, Fox AJ, JOnes DR. Unemployment and mortality: comparison of the 1971 and 1981 longitudinal census samples. Br Med $\mathcal{J}$ 1987;294:86-90.

8 Banks MH, Jackson PR. Unemployment and risk of minor psychiatric disorder in young people: cross

9 Platt S. Unemployment and suicidal behaviour: a review of the literature. Soc Sci Med 1984;19: 93-115.

10 Beale $\mathrm{N}$, Nethercott $\mathrm{S}$. Job loss and family morbidity: a study of factory closure. $f(R$ Coll Gen Pract 1985;280:510-4.

11 Unemployment and Health Study Group. Unemployment, health, and social policy. Leeds: Nuffield Centre for Health Services Studies, 1984

12 Smith R. Improving the health of the unemployed: a job for health authorities and health workers. BrMed f 1986;292:470-2.

13 Jones JJ. Occupationless health. Br Med f 1986;292:625.

14 McVey D, Barnett C, Hodge H. Guide to the MSC community programme. Liverpool: South Sefton Health Authority, 1986 .

15 Smith R. Training and "work" for the unemployed. BrMed f 1986;292:320-3.

(Accepted 18 March 1987)

\section{MATERIA NON MEDICA}

\section{The English game}

Avid readers of this feature who are also avid followers of cricket may have felt a vague stirring of the memory when reading reports of the recent MCC tour of Australia. On 29 October England played the South Australia Country XI at Wudinna. Wudinna? The old school atlas would have been no help in locating the place, and in Australia itself only detailed road maps show the name of this little town situated seven miles short of dead centre between Sydney and Perth. But the name has appeared in the BMF. This is the town that celebrates Christmas by butting at barrels of beer, an event known locally as the "Christmas Keg Roll" and described in this section a couple of years back.

Cricket has a strong following in Australian country areas, and it is the kind of relaxed, delightful cricket that was imported direct from the English village green even though, in South Australia at least, the majority of players are descendants of Irish, German, or Cornish settlers - communities that cannot be said to have a strong cricketing tradition. In few places is the word "green" apposite, the predominant colour being a hot, dry brown; Wudinna was chosen because it boasts the only turf wicket for 1000 miles west of Port Augusta.

Country cricket has an enthusiastic following in the Pacific islands as well. Albert Wendt, the doyen of native South Pacific writers, now ensconced in the English faculty of the University of the South Pacific, gave a lovely description in the Australian Bulletin of the Samoan modification of the game, where sides are not limited to a paltry and elite eleven but whole villages do battle. In the scattered Lau group of the Fiji Islands each little village has three great constants: a church, a copra dryer, and a concrete cricket pitch. In the relative cool of a summer's evening you can see all the youngsters of a village gathered together on the open green near the village church to worship the gods of leather and willow. Cream flannels are conspicuous by their absence, and I suspect that this may be one of the reasons why the South Pacific islands have failed to reach the incredible standards achieved in the Caribbean. The traditional Pacific masculine dress is the lavalava or sulu, a length of material wrapped around the waist as a skirt. Pace the Women's Cricket Association, how do you execute a full blooded hook or cover drive with a skirt flying up round the hips? How can you come thundering in on a $\mathbf{3 0}$ yard run and give a Holding leap before delivering a rocket when your first instinct is to grab at a wide splitting skirt? Of course this theory does nothing to explain the failure of Fiji to produce the elegance of a Gomes or the subtle witchcraft of a Ramadhin from its Indian inhabitants; why shouldn't one be a good scientist and conveniently ignore facts which don't fit in?

Organised cricket in Fiji is largely the creation of one man, Phillip Snow (brother of the more famous CP), who came to the islands as a district officer in 1938 and in his retirement has for years represenjed Fiji at the Imperial Cricket Conference. He gives a wonderful description of the development of cricket in the South Pacific-and of his contribution to it-in his book Cricket in the Fiji Islands. Published in New Zealand in 1949, this is difficult to obtain, but it is well worth while searching out not only for its description of Kirikiti but also for its subtle evocation of "Empire." There are those who believe that the history of the world would have been different (and better) had the American colonies separated off after the men of Hambledon had spread their influence throughout England, thus making the national game of the United States one played with a flat bat held vertically instead of a round bat held horizontally. There are also those who believe that the lasting contributions made by the imperial system to the colonies were an independent civil service, a medical ethos based on the best that London and Edinburgh had to offer, and that strange, irrational, and ever fascinating game called cricket.

M SOROKIN, consultant physician, Suva, Fiji. 